\title{
URANG BANJAR PHILOSOPHY: EDUCATION AND THE SOCIAL AFFAIRS OF THE COMMUNITY
}

\author{
Anwar Hafidzi \\ Faculty of Shariah Antasari State Islamic University Banjarmasin \\ E-mail: anwar.hafidzi@gmail.com
}

\begin{abstract}
The possibility of social change in the urang Banjar ideology is illustrated in this study. The people of Banjar demonstrate that farming is to be taught for the next generation, not just for the economies alone Bahuma or right farming. This research is field research with a descriptive-analytical approach. This research found that the philosophics of the traditions of Banjar should thrive wherever they are, with the approach of longitude (honesty, trust and fathanah), superficial (persistent and resilient), tugul (diligent and continuity), paibadah (near to God), batarget (sight and a clear mission). This paper is based on al-Qur'an surah Al-Fath verse 29 and alA'raaf verse 56 and supports Ashabiyah Ibn Khaldun's theory, which emphasizes that three stages tend to change people's thinking, namely the stage of creation, the stage of enjoyment, and the stage of individuality. Likewise, Arnold Toynbee's theory, which suggests that changes that happen in society, whether they are improvement or failure, can be explained by social concepts that are always interrelated, namely challenges and responses.
\end{abstract}

Keywords: Bahuma, Banjar, society, technology, change, education.

\section{A. PHILOSOPHICAL BASIS}

The Banjar, broadly speaking, is indigenous to part of the province of South Kalimantan. The majority of the population is located in the Banjarmasin area and extends to the Martapura area. No wonder if people want to go to Banjarmasin, they call it "Labuh to Banjar" the Banjar tribe has an indigenous language, the Banjar language, although 
they will have different dialects in each city in the Southern Kalimantan region by mentioning the language introductory ${ }^{1}$.

Azyumardi Azra said Sheik Arsyad al-Banjari's Islamic intellectuals network was able to embrace several kingdoms of Banjar to unite in defeating the invaders of the Netherlands. The Banjar tribe's original inhabitants extend to the river's border, no wonder Alfani Daud divides this tribe into two, namely the Pahuluan and Batang Banyu areas, based on the habit of the residents calling it. Batang banyu means the river, and some call it the river Nagara, with the valley area along the river Nagara downstream to Margasari and the town of Banjar and part of the river Tabalong ${ }^{2}$.

According to Ahmad Barjie, most of the Banjar people adhered to the religion inherited from their ancestors, there was no wonder that many beliefs emerged from the Banjar people's customs and traditions. Most Banjar tribal people adhere to Islam's religion, although a variety of animism and dynamism has been reported to exist ${ }^{3}$. This is demonstrated by the appearance of different terms with specific ritual practices in Banjar society.

The ritual system and the ceremonial belief system are not the only part of the confidence of a Banjar family. First, a belief derived from Islamic teachings taken from several interpretations of the use of the pillars of faith in Islam. Second, the belief by following the former as a mass practice, by looking at various taboo and pamali statements in daily life, results from the experience of the Banjar kingdoms ${ }^{4}$. Such beliefs are usually required to perform annual ceremonies, which are commonly referred to as "Acara Aruh". Third, the environment becomes part of the supernatural, thus requiring the public to perform various rituals of trust to see the goodness of an incident around it. It can be seen from these

${ }^{1}$ Eka Suryatin, “Analisis Semantik Verba Bermakna'Menyakiti'dalam Bahasa Banjar," Metalingua: Jurnal Penelitian Bahasa 12, no. 1 (2017): 43-56.

2 Michael R. Dove, "Peasant versus Government Perception and Use of the Environment: A Case-Study of Banjarese Ecology and River Basin Development in South Kalimantan," Journal of Southeast Asian Studies 17, no. 1 (1986): 113-136.

${ }^{3}$ Almu Noor Romadoni, “THE ETHNOMATEMATICS ASPECTS OF BANJAR CULTURE IN BALANGAN DISTRICT OF SOUTH KALIMANTAN” (n.d.).

${ }^{4}$ Pinky Saptandari, "Indonesian Spa and Traditional Wellness: Gender, Health and Life Styles," Health 5, no. 3 (2014): 20-31. 
three beliefs, that in reality, people's behavior is inseparable from a supernatural belief.

Such different issues give the writer an impetus to investigate the city of Banjar with specific sociological perspectives from the culture of Banjar, Bahuma. Bahuma is taken from the Banjar language, meaning there is farming or rice growing, this practice is usually performed in a fertile place and flowing waters or called rice fields.

Urang Banjar turned out to have different farming or bahuma habits and became day-to-day work to build the family economy. This fact makes investigators want to see the work's sociological theoretical implications and the findings benefits ${ }^{5}$. The results of this study will contribute to cultural and educational growth, particularly in South Kalimantan's Banjar District.

\section{B. RESEARCH OF METHODOLOGY}

This study uses the City of South Kalimantan as a research location and is sampled by grounded research based on simultaneous data mining in the field with the theoretical assumptions of the field itself focusing on social change research from the Banjar people's livelihoods and the theory assumption must be successful while working is the main asset in enriching Bahuma's analysis This research is aimed more at the research field supported by some literature which is considered qualified to examine the social development of the Banjar community by examining it with the approach and reflection of sociological phenomena ${ }^{6}$.

The data source in this study is people who can provide different research-related information. By purposeful sampling, the persons handled in this study was decided with the following steps: to determine initial information, an informant who was able to provide all the necessary information was found for this research ${ }^{7}$. Understanding the implementation of bahuma and its importance to religious education's

${ }^{5}$ Asim Gunarwan, "Indonesian and Banjarese Malay among Banjarese Ethnics in Banjarmasin City: A Case of Diglossia Leakage?.” (2001).

${ }^{6}$ Martin Bulmer, Sociological Research Methods (Routledge, 2017).

${ }^{7}$ Bruce H. Mayhew, "Baseline Models of Sociological Phenomena," Journal of Mathematical Sociology 9, no. 4 (1984): 259-281. 
successful life is important. Data gathered through in-depth interviews with informants often pursued significance in connection with "bahuma."

\section{BAHUMA: A REFLECTION OF BANJAR BELIEFS RITUAL}

Farming activities by people preliminary (as people who live on the upstream river) are known, are a source of livelihood for the Banjar people, including the Banjar area. Quoting from Alfani Daud $(437,1997)$ explains that when the rice seeds will be sown "dirabun", that is smoked on perapen fire with smoke while saying "kur sumangat" many times, then when the rice is put into the water the Surah is recited. Fatihah once and pray three times. When going to start Manaradak, usually held salvation by preparing kokoleh and then read congratulations ${ }^{8}$.

The activity of planting rice has been carried out since planting the last rice child in a paddy field. The activity bamula is to start planting rice by holding aby preparing salvage kokoleh which is then eaten together in the middle of the rice fields. Before the rice is planted, a bamula ceremony is also carried out, by asking for help from people who are considered "experts" to be held in the afternoon ${ }^{9}$. After being planted, part of the rice is then processed into a porridge which will be served during the "mahanyari banih" salvage event. If the rice is neat inside the granary located in one corner of the house, a ceremony is held to surround the rice offering (Daud, 1997: 445). This is done by Banjar residents by giving rice to the community by eating together, as a sign of gratitude to God, even though it was once a form of offering.

The informant from Batu Pahat, Malaysia, explained that since the expansion into the neighboring country, all the yellow rituals have been maintained until now, this is related to the de facto myth of the yellow crocodile as a symbol of the Banjar people's movement against the invaders Wulanda as the Dutch. The incident was not intentional, but a magical creature who came to the Banjar residents 'homes and offered services to protect the house from Dutch invaders attack, strangely this is indeed true, no one dared to attack the residents' houses because of the number of crocodiles in front of the house. This ritual is usually done

${ }^{8}$ Karel A. Steinbrink, Dutch Colonialism and Indonesian Islam: Contacts and Conflicts, 1596-1950, vol. 7 (Rodopi, 2006).

${ }^{9}$ Dove, "Peasant versus Government Perception and Use of the Environment." 
once a year and this is not his will but based on the descendants who guard it, by calling his names in water and being handed food, usually done on the eve of the Eid al-Adha feast day ${ }^{10}$.

So it goes, so that Banjar residents are very familiar with the term piduduk when performing a wedding celebration, whether by accident or indeed orders from their ancestors. God knows best. However, many informants said that putting it was not for shirk, but merely putting it down, this was done so that the intention was not towards shirk.

\section{THE BAHUMA PHILOSOPHY: THE ROLE OF EDUCATION IN VILLAGE DEVELOPMENT}

From discussions with various elements of society, Banjar residents have a typical democratic, religious, egalitarian, independent and have goals that must be achieved. Religious-based education to be the main thing in achieving educational goals urang Banjar. The aim is to be beneficial for the worldly and akhirah by mastering soft skills and hard skills ready to train like the philosophy Bahuma.

Religious preparation is an anticipation of what will be the challenges of life for their children in the future. So that many parents send their children to religious schools from an early age, and continue to develop with the times. There are assumptions in the 80-90s for those who send to public education to be considered a Christian school, this is because religiosity is the most important part in achieving successful education, then the assumption "if sane explosives are successful, say religion" means if you want to achieve success, then the role of religion should not be forgotten ${ }^{11}$. It is reported that the Banjar community has three characters in bahuma:

1. The process in which bahuma is merely bahuma, there are no religious values in its implementation. Usually, the results will be spent based

${ }^{10}$ Meidwinna Vania Michiani and Junichiro Asano, “A Study on the Historical Transformation of Physical Feature and Room Layout of Banjarese House in the Context of Preservation," Urban and Regional Planning Review 4 (2017): 71-89.

${ }^{11}$ Basuki Sumawinata, "Soil Chemical Profiles Developed from PyriteContaining Sediments under Banjarese Agricultural Practices in South Kalimantan," Japanese Journal of Southeast Asian Studies 36, no. 4 (1999): 475-493. 
on the needs of the satisfaction of the liver for a moment. This can be seen by the many benefits and many are also spent without feeling.

2. The process is bahuma based on promoting economic quality. This situation is usually characterized by the number of items purchased in the form of investment, such as gold, land, or transportation. This type of information, according to some informants in bahuma, will use a lot of calculations, and to achieve maximum goals, usually with minimal capital.

3. The process is bahuma based on Islamic religious values. This process is usually passed on by parents or progenitor in preparing bahuma, these preparations although they are Islamic, there are still some rituals of the belief that are still adhered to. Rice products obtained are intended for the benefit of the world and the hereafter.

According to some informants, this philosophy has become a tradition for the Banjar people to be successful wherever they are, especially with support having to get out of the Banjar to the City or other regions to symbolize the existence of a society that has the trust of a buhaya (crocodile). Of course, based on this approach, many informants who are successful outside Banjar even get to Batu Pahat Johor Malaysia who convey that the philosophy of bahuma should not be forgotten with the approach longitude (honest, trustworthy, and fathanah), superficial (diligent and tenacious), tugul (diligent and continuity), paibadah (close to God), batargetclear (vision and mission), kahilir (moving to a place), nahap (meticulous) ${ }^{12}$. While for those who do not comply with religious rules, many are also considered to have failed when they were in banua urang.

\section{E. URANG BANJAR: SOCIAL CHANGE AND INEQUALITY}

Studying social change in society is certainly inseparable from the causes of these changes. It can be said that the social change of an area occurs

${ }^{12}$ Sumasno Hadi, "Studi Etika Tentang Ajaran-Ajaran Moral Masyarakat

Banjar," Jurnal Tashwir 3, no. 6 (2015); M. Rafiek M. Rafiek, "Pemasyarakatan Bahasa Indonesia Melalui Madihin Banjar Jhon Tralala Dan Hendra Sebagai Upaya Mempererat Persatuan Bangsa Indonesia (The Socialization Of Indonesian Language Through Madihin Banjar By Jhon Tralala And Hendra As Efforts To Strengthen National Unity Of Indonesia)," JURNAL BAHASA, SASTRA DAN PEMBELAJARANNYA (JBSP) 3, no. 2 (2018): 184-195. 
because of people's dissatisfaction with the old life. The assumption of a change in the Banjar community is in the form of the economy (while others the authors do not analyze it), where many of the pahumaan have been transformed into house land or sleeping land left by their descendants who are successful with other jobs.

The author sees from various religious beliefs and rituals in bahuma there are at least 4 (four) factors that cause social changes that occur in Banjar community together or individually:

1. Increasing or Declining Population

The existence of urbanization that uses the philosophy that in the city will be successful causing many of the people to go to the city to try their luck, but on the other hand they are creating new unemployment. Meanwhile, the unpreparedness of the community such as its philosophy even adds to the burden on the city, and the result of the village being abandoned causes a vacuum in the area left behind.

Things like this will lead to changes in the employment system, social stratification, leaving the work of parents, and the need to reach a prosperous economy makes many land pahumaan sold for novelty. Reportedly at present, the land pahumaan in Banjar is done by the oldest child, while others prefer jobs that are considered better.

For example, the migration of farmers or their offspring to big cities causes agricultural land to become dysfunctional. Some have even been mortgaged for family economic interests.

The dysfunction of agricultural land, of course, has an impact on the pattern of division of labor in each family which ultimately drives changes to the overall economic system of society. Not surprisingly, villages with large agricultural land still buy rice to the market for daily needs.

2. Society's Luxury Condition

Appears among the rich people with various colors of life will also lead to unbalanced strata. Rich people will begin to separate their lives from the poor, or vice versa. This social gap also results in a change in the principle of bahuma namely by working together to achieve success. 
This will be considered part of an achievement so that many citizens strive to succeed. Most informants said, Banjar people are still accustomed to rural life, although it can be seen that every holiday there are various types of cars parked in front of the house, the question is whether the city actually achieved success or maybe because of prestige, both writers get from conversation with people in the market Banjar.

3. Conflict in the Community: Internal and External

Conflicts or conflicts that in the community can at least bring about social change, both in the form of internal or external conflict. Conflict with parents or family members can at least encourage polemics in social change. Likewise with conflicts that occur with neighbors will bring apathy towards the situation and eventually will be individualistic towards others.

In Banjar itself, external conflicts rarely occur, although there are many migrants with different racial tribes, which sometimes make trouble in the community not to discourage the socialist nature of Banjar citizens. Even if it does, it usually doesn't lead to a fight, but there is always a feeling of discomfort among the residents. So it is natural that Banjar has a very high tolerance for circumstances. Reportedly a lot happens is an internal conflict, where children no longer want to work on the inheritance of their ancestors due to the assumption of modern times. While there are also parents who do not want their children to work like what their parents do. This can be seen from the work approach, conveyed the philosophy that bahuma must be superficial or diligent is an important part in achieving success

4. Education and Employment Status

No doubt, Banjar people who are religious are still concerned with the religion of others. Seen with various religious activities that remain harmoniously interwoven, this is evidenced by a variety of religious activities that remain preserved, majelis taklim, the sacred tomb of Datu Nafis, the Banua Lawas mosque which is the Banjar cultural style. The advance of science and technology requires parents to send their children to a higher level, so the harvest from rice is used for religious education. Because some people think that religion is the 
pillar of everything, the term used by informants is "if jackfruit is planted and maintained from the beginning the fruit will not fall easily" meaning that the jackfruit which has a large diameter will not be separated from its branches if cared for properly. Wherever they are, they are still taught by religion, taught from a young age, and will continue to be in the minds of every Muslim.

The author sees many Banjar residents who are currently gaining success in banua urang, this is evidenced by the halal bi halal event in Tabalong residents in Banjarmasin with a variety of well-known professions and occupations. However, if you look at Banjar village, there is nothing to be proud of from your assets, but honest, honest capital, the diligent wan makes this rural community city-minded and Islamic-minded.

\section{F. CONCLUSION}

Education The secret to the accomplishment of educational goals is the advancement of faith. Religion. Religious planning is an anticipation of what life's future challenges will be for your children. The goal is that the world and afterlife benefit by mastering soft skills and hard skills that are ready to train like the Bahuma philosophy. This philosophy has become the tradition of Banjara people to thrive wherever they are. They have an approach which is longitudinal (trustworthy, truthful and Fathanah), superficial (persistent and resilient), tugul (diligent and consistent). With the development of the 21 st century, however, this philosophy began to erode by making technostress a foothold and making kids individual. The most significant change in Banjar society is that religion should in different ways be prioritized in accordance with the values of the bahuma philosophy.

\section{REFERENCE}

Bulmer, Martin. Sociological Research Methods. Routledge, 2017.

Dove, Michael R. "Peasant versus Government Perception and Use of the Environment: A Case-Study of Banjarese Ecology and River Basin Development in South Kalimantan." Journal of Southeast Asian Studies 17, no. 1 (1986): 113-136. 
Gunarwan, Asim. "Indonesian and Banjarese Malay among Banjarese Ethnics in Banjarmasin City: A Case of Diglossia Leakage?." (2001).

Hadi, Sumasno. "Studi Etika Tentang Ajaran-Ajaran Moral Masyarakat Banjar." Jurnal Tashwir 3, no. 6 (2015).

Mayhew, Bruce H. "Baseline Models of Sociological Phenomena." Journal of Mathematical Sociology 9, no. 4 (1984): 259-281.

Michiani, Meidwinna Vania, and Junichiro Asano. "A Study on the Historical Transformation of Physical Feature and Room Layout of Banjarese House in the Context of Preservation." Urban and Regional Planning Review 4 (2017): 71-89.

Rafiek, M. Rafiek M. "Pemasyarakatan Bahasa Indonesia Melalui Madihin Banjar Jhon Tralala Dan Hendra Sebagai Upaya Mempererat Persatuan Bangsa Indonesia (The Socialization Of Indonesian Language Through Madihin Banjar By Jhon Tralala And Hendra As Efforts To Strengthen National Unity Of Indonesia)." JURNAL BAHASA, SASTRA DAN PEMBELAJARANNYA (JBSP) 3, no. 2 (2018): 184-195.

Romadoni, Almu Noor. "THE ETHNOMATEMATICS ASPECTS OF BANJAR CULTURE IN BALANGAN DISTRICT OF SOUTH KALIMANTAN" (n.d.).

Saptandari, Pinky. "Indonesian Spa and Traditional Wellness: Gender, Health and Life Styles." Health 5, no. 3 (2014): 20-31.

Steenbrink, Karel A. Dutch Colonialism and Indonesian Islam: Contacts and Conflicts, 1596-1950. Vol. 7. Rodopi, 2006.

Sumawinata, Basuki. "Soil Chemical Profiles Developed from PyriteContaining Sediments under Banjarese Agricultural Practices in South Kalimantan." Japanese Journal of Southeast Asian Studies 36, no. 4 (1999): 475-493.

Suryatin, Eka. "Analisis Semantik Verba Bermakna'Menyakiti'dalam Bahasa Banjar." Metalingua: Jurnal Penelitian Bahasa 12, no. 1 (2017): 43-56. 